Full-text Available Online at www.ajol.info and www.bioline.org.br/ja
J. Appl. Sci. Environ. Manage. Sept 2013

Vol. 17 (3) 433-438

\title{
Antiproliferative and Pro-apoptotic activities of the stem bark of Persea Americana (lauraceae) mill in Human Breast Adenocarcinoma Cell Line
}

\section{ABIODUN FALODUN ${ }^{1 *}$, HENRIETTA IYAMABO ${ }^{1}$, EMMANUEL EIMIOMODEBHEKI ODION ${ }^{1}$, NADJA ENGEL- LUTZ ${ }^{2}$,}

\author{
${ }^{I}$ Department of Pharmaceutical Chemistry, Faculty of Pharmacy, University of Benin, \\ Benin City, Edo State, Nigeria \\ ${ }^{2}$ University of Rostock Medical Faculty, Department of Cell Biology \\ Schillingallee 69, 18057 Rostock, Germany
}
*Corresponding address: faloabi@uniben.edu
Tel.: +234(0)8073184488

Keyword: Persea americana, antiproliferative activity, apoptotic effect, flow cytometer, proximate analysis

\begin{abstract}
Persea americana (Lauraceae) have been used in traditional medicine for a wide range of illness and some of these uses have been proven scientifically. The aim of this present study is to screen for the phytochemical content, determine the proximate parameter and determine the antiproliferative and apoptotic effects of the stem bark of Persea americana in MCF-7 cell line by flow cytometer. Result of the phytochemical screening showed the presence of carbohydrate, reducing sugar, tannins, saponin and alkaloid. Proximate analysis gave moisture content of $13.82 \pm 0.24 \%$, acid insoluble ash of $1.17 \pm 0.15 \%$, alcohol soluble extract $2.13 \pm 0.14 \%$ and water soluble extractive $1.67 \pm 0.07 \%$. It lacks both antiproliferative and apoptotic activities in MCF-7 cell line but significantly reduced the percentage of cells in $\mathrm{G} 2$ phase of the cell cycle $(\mathrm{P}<0.1)$. These results showed that the stem barks of Persea americana contained compounds that may be responsible for it activity. @JASEM
\end{abstract}

http://dx.doi.org/10.4314/jasem.v17i3.13

Cancer is a leading cause of death in both developed and developing countries, its accounted for 7.6 million deaths (13\% of all deaths) in 2008. While the under developed and medium income countries record about $70 \%$ death as a result of cancer and it is predicted that by the year 2030,over 13.1 million death will be recorded annually (Globocan, 2008) . The causes of cancer vary, recent studies have shown microbes to be implicated (Cover and Blaser, 1995). Micro organisms produces effects which ranges from causing infections, spoilage of food items, etc (Azu and Onyeagba, 2007), (Blackwell, 2006). However, some of these microbes have produce compound of great benefit to man including chemotherapeutic agents (Schatz and Waksman, 1944) .These lead compounds need to be purified and isolated using varoius methods of separation (Dinan et al., 2001). The use of plants in medicine either in its powdered form or as lead source for the discovery of new compounds with better therapeutic potentials is an area that continues to enjoy patronage by researchers. Plants are known to possess compounds through which they exert actions that may be of importance to man, animal and its environment (Nguyen, 1999). Lauraceae is the laurel family, with 3000 species of flowering plants in over 50 genera worldwide. They are native to warm temperate and tropical regions, especially Southeast Asia and South America. Most are aromatic evergreen trees or shrubs, usually $9 \mathrm{~m}$ to $18 \mathrm{~m}$ or more, trunk $30-60 \mathrm{~cm}$ in diameter, and can be greater in very old trees. It fruits are pear-shaped, which may be $7.5-33 \mathrm{~cm}$ long and up to $15 \mathrm{~cm}$ wide. The colour of the skin varies from yellow to purple, which may be smooth or leathery and up to $6 \mathrm{~mm}$ thick. Immediately under the skin there is a thin layer of soft fruit, buttery and bland in flavour. It produces single seeds of different shapes, 5-6.4 cm long, some fruits are seedless because of lack of pollination or other factors (Burkill, 1995). Common names of $P$. americana include alligator pear, avocado, avocadopear, butter pear, vegetable pear and butter fruit (Yasir et al., 2010), (Lans, 2006). It is used in folk medicine for the treatment of tumor, hypertension, diabetes, inflammation, sore throat, haemorrhage vermifuge, dysentery and as aphrodisiac (Lans, 2006), (Bartholomew, 2007), (Gill, 1992), (Ayinde et al., 2011), (Adeyemi et al., 2002), (Edem et al., 2009), (Yasir et al., 2010). Scientifically, some of these activities have been evaluated, for example the antihypertensive, anticonvulsant, analgesic and anti- 
inflammatory effects. (Gill, 1992), (Yasir et al., 2010), (Edem et al., 2009), (Ojewole et al., 2007), (Ojewole and Amabeoku, 2006), (Owolabi et al., 2005). This present study was designed to screen the phytochemical content, determine the proximate parameters, evaluate the antimicrobial, antiproliferative and apoptotic activities of the stem bark of $P$. americana in MCF-7 cell line and also to partially characterize the petroleum ether fraction using chromatographic analyses.

\section{MATERIALS AND METHOD}

COLLECTION OF PLANT MATERIAL: The stem bark of $P$. americana was collected within University of Benin, staff quarters B17 in September, 2011 from Ovia North-East local government area in Edo State, Nigeria by Mr. Kingsley Ugwu. The plant was identified and authenticated by Prof. MacDonald Idu of the department of Plant Biology and Biotechnology.

The fresh stem bark were carefully washed with water to remove earthy material and air-dried for a period of one week, after which they were placed in the oven for thirty minutes at a temperature of $40^{\circ} \mathrm{C}$, before they were reduced to fine powder with the aid of an electric milling machine. The powdered sample was stored in an air tight container until used.

Extraction of Powdered root Bark: Powdered sample $(700 \mathrm{~g})$ was macerated at room temperature with 2.5 litres of methanol at room temperature for $72 \mathrm{hrs}$ (Brain and Turner, 1975). The filtrate was concentrated with a rotary evaporator at $40^{\circ} \mathrm{C}$ under reduced pressure. The total yield obtained was 19.53 g $(2.79 \%)$. The concentrated extract was stored in a refrigerator at $4^{0} \mathrm{C}$ until used. The dried extract $(15$ g) was partitioned into Petroleum ether $\left(40-60^{\circ} \mathrm{C}\right)$ (PET), chloroform (CH), and ethylacetate (ET) respectively.

Phytochemical Screening: Chemical tests were carried out on the powdered drug for the qualitative determination of phytochemical constituents as described by (Harborne, 1973), (Trease and Evans, 1989) and (Sofowora, 1993). This involves test for carbohydrate, reducing sugar, saponins, alkaloids, tannins and flavonoids.

Proximate Analysis of the Powdered Drug: The following quantitative parameters were carried using standard methods (African Pharmacopoeia, 1986; British Pharmacopoeia, 1988 ; AOAC, 2003); moisture content, acid insoluble ash, alcohol soluble extractive and water soluble extractive.
Cell Culture: All cell line were obtained from the American Type Culture Collection (Manassas, VA, USA) and maintained at $37^{\circ} \mathrm{C}$ and in $5 \% \mathrm{CO}_{2}$ atmosphere in a monolayer. Confluent cells will be passaged by treating them with $0.05 \%$ trypsin- $0.02 \%$ EDTA.

Treatment with Plant Extract: For all experiments 0.5 $\mathrm{x} 10^{6}$ cells were seeded in a 6-well plate in regular culture medium for 24 hours. Subsequently, cells line were washed with phosphate buffer saline (PBS) and adapted to phenol-red-free Dulbecco's modified Eagle's medium for 48 hours to avoid unspecific stimulation of endogenous hormones in the serum. Treatment with plant extracts (final concentration 10 $\mathrm{ug} / \mathrm{ml})$ and DMSO (0.1\%) was done.

Flow Cytometric Measurement Of Cell Proliferation: The extent of cell cycle progression and apoptosis was estimated by flow cytometric analysis (Nadja et al., 2011). For statistical evaluation, the S-phase and G2/M-phase cells were defined as proliferative cells.

Statistical Analysis: Every experiment was replicated three times; data sets were expressed as mean \pm standard deviations (SD). Statistical significance was determine by unpaired t-test $(* * * \mathrm{P}<0.001$, $* * \mathrm{P}<$ $0.01, * \mathrm{P}<0.1)$.

\section{RESULT AND DISCUSSION}

The powdered stem bark of $P$. americana gave a yield of $4.21 \%$ after extraction with methanol (Table 1). This low yield could be attributable to the method use for extraction which in this case is maceration and this could be due to the inability of methanol to extract sufficient amount of relevant material. Also, it will be observed that fractionation of the crude extract with solvents of increasing polarity have resulted in the production of fractions with decrease quantity as the polarity of the solvents increase, indicating that the crude extract possesses high level of non polar content. The phytochemical constituent of powdered stem bark indicates the presence of carbohydrates, reducing sugar, saponins, alkaloids and tannins while flavonoid was absent (Table 2). This result does not agree with previous work, which showed the presence of flavonoid and absence of alkaloid in the stem bark of $P$. americana (Ayinde, 2011). However this observation may be due to differences in the location of the plant since the presence of phytochemicals can be influence by environment in which the plant is grown (Folkers et al, 2008; Shen et al. 2008). The proximate analysis carried out on the stem bark of $P$. americana gave a moisture content of $13.82 \pm 0.24 \%$, acid insoluble

\section{ABIODUN FALODUN ${ }^{*}$, HENRIETTA IYAMABO ${ }^{1}$, EMMANUEL EIMIOMODEBHEKI ODION ${ }^{1}$, NADJA ENGEL- LUTZ ${ }^{2}$,}


ash $1.17 \pm 0.15 \%$, alcohol soluble extractive $2.13 \pm$ 0.14 and water soluble extractive $1.67 \pm 0.07 \%$ (Table 3). It will be observed that the moisture content is high and thus is a strong indication that the powdered stem bark is susceptible to microbial attack. Implying that long time storage of the powdered stem bark may lead to its degradation. The acid insoluble ash value of the stem bark is low showing that the stem bark contains low level of inorganic constituents, like sand. The extractive value is used to determine the best solvents for the extraction of the chemical constituents from the plant samples. The alcohol soluble extractive value is higher than the water soluble extractive values for the stem bark, showing that alcohol will extract more of the chemical constituents present in the stem bark than water. Cell cycle analysis (Figure 1), shows the percentage number of cells in the G2 phase after treatment with the crude extract of $P$. americana (SBPA) to be $14.80 \%$, while the control (DMSO) which was used to dissolve the crude extract produced $20.74 \%$. This shows a significant decrease of $5.94 \%$ in the percentage number of cells $(\mathrm{P}<0.1)$. The $\mathrm{S}$ phase also show the percentage number of cell to be $12.10 \%$ for SBPA treated cells and $11.37 \%$ for DMSO treated cells, giving $0.73 \%$ increase in percentage number of cells which is not significant. G1 phase show percentage number of MCF-7 cells after treatment with SBPA to be $73.10 \%$, this show a decrease of $4.09 \%$ when it was compared with the control $(68.11 \%)$. MCF-7 cell cycle analysis post treatment with SBPA shows the percentage of proliferative cells to be $26.90 \%$ (Figure 2), while DSMO treated cells gave $31.88 \%$. This shows a decrease in the percentage of proliferative cells of $4.98 \%$, this was not significant. Extent of apoptosis was also evaluated (Figure 3) and it was observed that the SBPA treated MCF-7 cells produced $6.47 \%$ apoptosis while DMSO treated cells show $6.26 \%$. This shows $0.21 \%$ increase in apoptotic cells, though not significant. These results show that SBPA lacks both antiproliferative and apoptotic activity even though it may have affected the cells in the G2 phase of the cell cycle. It is may have produced this effect by activating G2 checkpoint which may be responsible for correcting the damage the cells may have encountered in the process of moving through the cycle.

Conclusion: The stem bark of $P$. americana is rich in phytochemical constituents that lacks antiproliferative and apoptotic effects in MCF-7 cell line. Chromatographic analysis confirmed the presence of a number of compounds in the stem bark extract.

Acknowledgement: The authors wish to thank Dr. Nanja-Lutz Engel of the University of Rostock for agreeing to analyze the effect of $P$. americana on MCF-7 cell line and to express gratitude to the Department of Pharmaceutical Chemistry, Faculty Pharmacy, University of Benin, Benin City for the facilities.

Table 1: Percentage yield of the powdered stem bark of $P$. americana

\begin{tabular}{ll}
\hline Extact/Fractions & Percentage yield (\%) \\
\hline Methanol extract & 4.21 \\
Petroleum ether & 19.51 \\
Chloroform & 13.7 \\
& \\
Ethyl acetate & 3.62 \\
\end{tabular}

Table 2: Phytochemical screening of the powder stem bark of $P$. americana

\begin{tabular}{lc}
\hline Carbohydrate & + \\
Reducing sugar & + \\
Tannin & + \\
Saponin & + \\
Alkaloid & + \\
Flavonoids & - \\
\hline \multicolumn{1}{c}{$+=$ Indicates presence of components } \\
$\quad=$ Indicates absence of components
\end{tabular}

$+=$ Indicates presence of components
$-=$ Indicates absence of components

\section{ABIODUN FALODUN ${ }^{1 *}$, HENRIETTA IYAMABO ${ }^{1}$, EMMANUEL EIMIOMODEBHEKI ODION ${ }^{1}$, NADJA ENGEL- LUTZ ${ }^{2}$,}


Table 3: Percentage (\%) values of proximate analysis of the stem bark of $P$. americana

\begin{tabular}{lc}
\hline Parameter & Values \pm SEM $(\%)$ \\
\hline Moisture content & $13.82 \pm 0.24$ \\
Acid insoluble ash & $1.17 \pm 0.15$ \\
Alcohol soluble extractive & $2.13 \pm 0.14$ \\
Water soluble extractive & $1.67 \pm 0.07$ \\
\hline
\end{tabular}

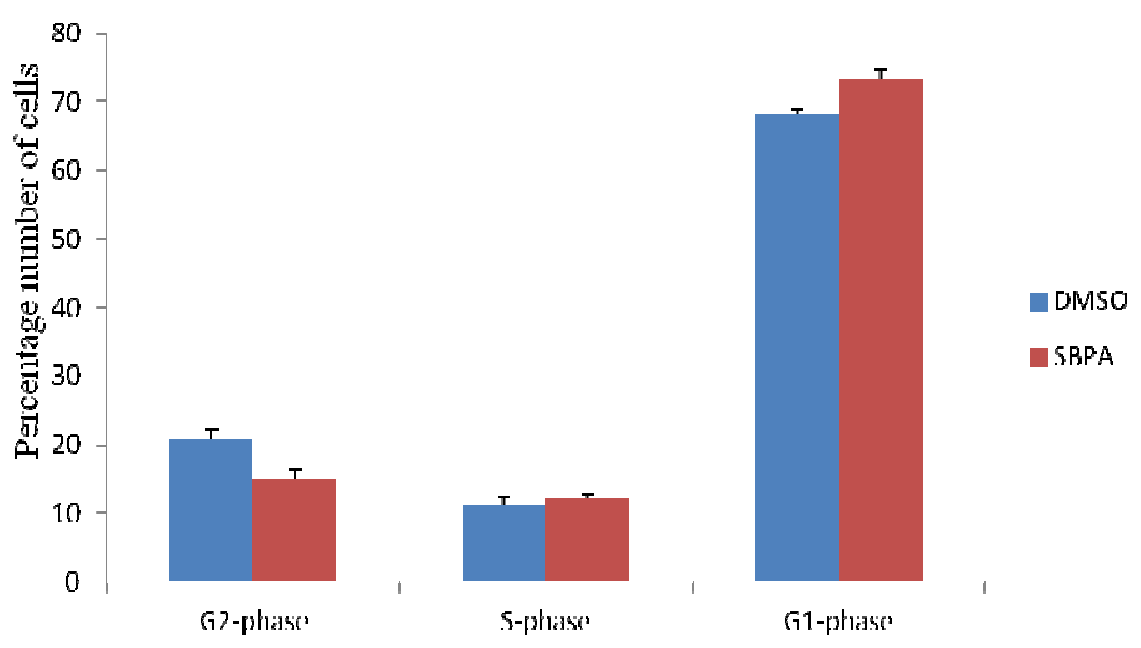

Fig1: percentage of human breast adenocarcinoma cell line (MCF-7) after treatment with the crude extract of $P$. americana and DMSO.

DMSO = Dimethylsulphoxide

$\mathrm{SBPA}=$ Stem bark of $P$. Americana

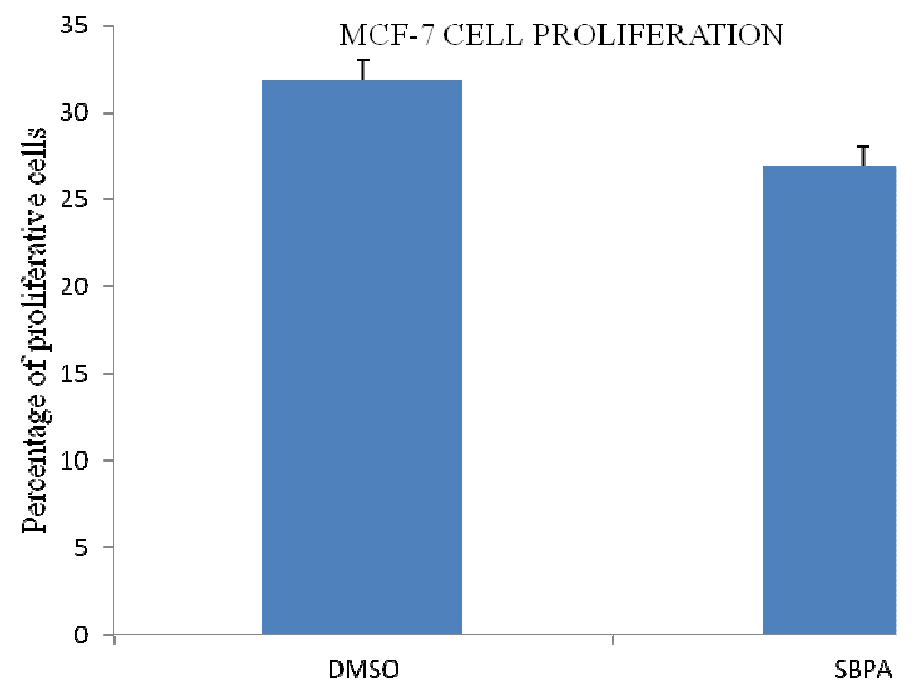

Fig 2: percentage of proliferation of human breast adenocarcinoma cell line (MCF-7) after treatment with the crude extract of $P$. americana and DMSO.

DMSO = Dimethylsulphoxide

SBPA = Stem bark of $P$. americana 


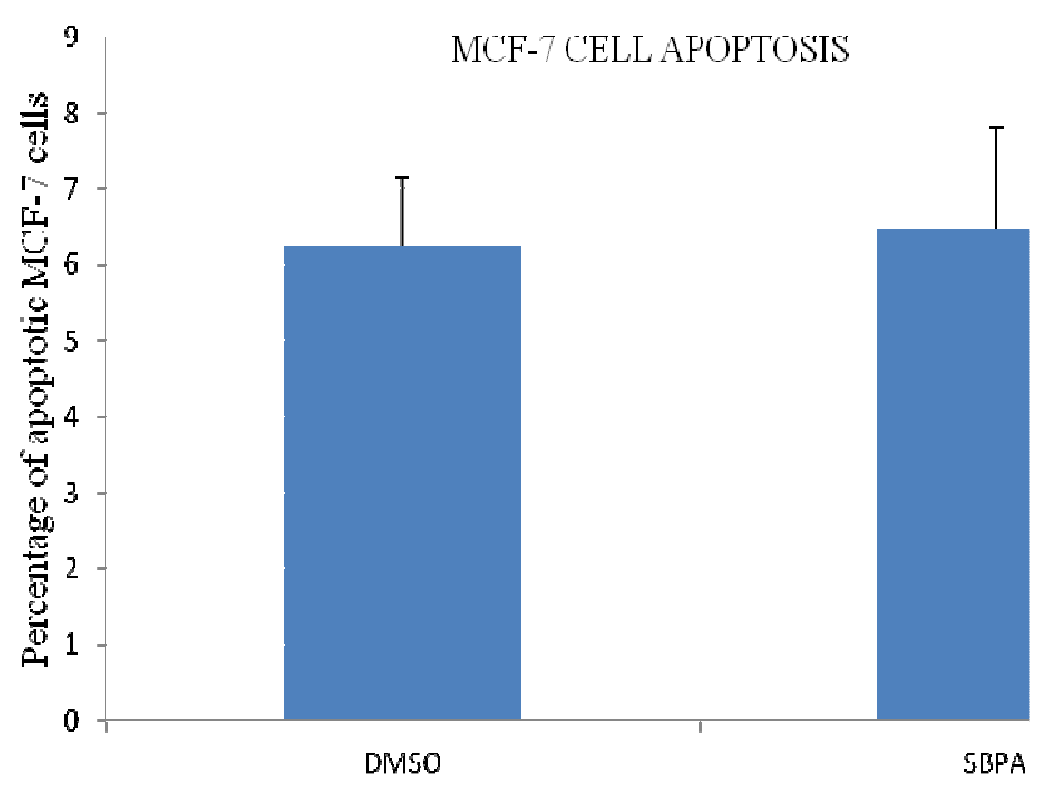

Fig 3: percentage of apoptosis of human breast adenocarcinoma cell line (MCF-7) after treatment with the

crude extract of $P$. americana and DMSO.

DMSO = Dimethylsulphoxide

SBPA $=$ Stem bark of $P$. americana

Acknowledgement: Special thanks to STEP B/World Bank grant, URPC VC23 research grant (2013) and to the Cell Biology, University of restock, Germany.

\section{REFERENCES}

Adeyemi, OO; Okpo, SO; Ogunti OO (2002). Analgesic and anti-inflammatory effect of the aqueous extract of leaves of Persea americana Mill (Lauraceae). Fitoterapia 73:375-380.

African Pharmacopoeia, (1985). Volume 1 ( $1^{\text {st }}$ eds) OAU/STRC publication 1:159

Ayinde, BA; Omogbai, EKI; Ikpefan, EO (2011). Comparative Cytotoxic and Antiproliferative Effects of Persea americana Mill (Lauraceae) Leaf, Stem and Root Barks. Nig. J. Pharm. Sci. 10(1): $16-26$.

Azu, NC; Onyeagba, RA (2007). Antimicrobial Properties Of Extracts Of Allium cepa (Onions) and Zingiber officinale (Ginger) On Escherichia coli, Salmonella typhi and Bacillus subtilis. Internet J. Tropical Med. 3. 2.
Bartholomew, ICB; Odetola, AA; Agomo, PU (2007). Hypoglycaemic and hypocholesterolemic potential of Persea Americana leaf extracts. J. Medicinal Food, 10: 356-360.

Blackwell, CDW (2006). Food spoilage micro organisms. Woodhead publising

Brain, KR ; Turner, T D (1975). The Practical Evaluation of Phytopharmaceuticals. WrightScientechnica. Bristol. 36-45.

Burkill, HM (1995). The Useful Plants of West Tropical Africa, Volume 3, Families J-L. Royal Botanic Gardens, Kew.

Cover,T L; Blaser, M J (1995). Helicobacter pylori: a bacterial cause of gastritis, peptic ulcer disease, and gastric cancer. ASM News 61:21-26

Dinan, L; Harmatha, J; Lafont R (2001). Review: Chromatographic procedures for the isolation of plant steroids. J Chromatography A, 935. 105123.

\section{ABIODUN FALODUN ${ }^{1 *}$, HENRIETTA IYAMABO ${ }^{1}$, EMMANUEL EIMIOMODEBHEKI ODION ${ }^{1}$, NADJA ENGEL- LUTZ ${ }^{2}$,}


Edem, DU; Ekanem, IS; Ebong, PE (2009). Effect of Aqueous Extracts of Alligator Pear Seed (Persea Americana Mill) on Blood Glucose and Histopathology of Pancreas in Alloxan-Induced Diabetic Rats. Pak. J. Pharm. Sci.22.3.272-276

Falodun, A; Josephs, GC; Okeri, HA; Oribhabor, A (2010). Partial chromatographic characterization and antimicrobial evaluation of Jatropha gossypifolia extract and its fractions. Biosci. Res. Comm. 22, 3.

Folkers, A; Huve, K; Ammann, C; Dindorf, T; Kesselmeier, J; Kleist, E; Kuhn, U; Uerlings, R; Wildt, J (2008). Methanol emmissions from deciduous tree species: dependence on temperature and light intensity. Plant Biol. 10 (1): $65-75$

Gill, LS (1992). Ethnomedical Uses of Plants in Nigeria. Uniben Press Benin, Nigeria.

Globocan, (International Agency for Research on Cancer) 2008. Section on cancer information. 24/9/2012.

Harborne, JB (1973). Phytochemical methods. Chapman and Hall Ltd.,London. 49-188.

Hugo, WB; Russel, AD (2003). Pharmaceutical Microbiology 6th Edition. Replica press PVt Ltd. 4-5.

Lans, AL (2006). Ethnomedicines used in Trinidad and Tobago for urinary problems and diabetes mellitus. J. ethnobio. and Ethnomed. 2: 45.
Yasir, M; Das, S; Kharya, MD (2010). The phytochemical and pharmacological profile of Persea americana Mill. Pharmacogn Rev. 4(7): 77-84.

guyen, TT (1999). The Cholesterol-Lowering Action of Plant Stanol Esters. J. Nutr.129.12. 2109-2112

Ojewole, JAO; Kamadiyaapa, DR; Gondwe, MM; Moodley, K; Musabayane, CT (2007). Cardiovascular effects of Persea Americana Mill (Lauraeae) (avocado) aqueous leaf extract in experimental animals. Cardiovas. J.South Afr. 18: 69-76.

Ojewole, JA; Amabeoku, GJ (2006). Anti-convulsant effect of Persea Americana Mill

(Laurceae) (Avocado) leaf aqueous extract in mice. Phytotherapy Research, 20: 696-700.

Owolabi, MA; Jaja, SI; Coker, HA (2005). Vasorelaxant action of aqueous extract of

the leaves of Persea Americana on the isolated thoracic rat aorta. Fitoterapia 76: 567-573.

Schatz, A; Waksman, SA (1944). Effect of streptomycin upon Mycobacterium tuberculosis and related organisms. Proc. Soc. Exptl. Biol. Med., 57:244-248

Sofowora, LA (1993). Medicinal plants and traditional medicine in Africa.Spectrum Books Ltd, Ibaban. Harborne. 55-71.

Trease, GE; Evans, WC (1989). Trease \& Evans' Pharmacognosy. 13th Edition. London: Bailliere Tindale. 832.

\section{ABIODUN FALODUN ${ }^{1 *}$, HENRIETTA IYAMABO ${ }^{1}$, EMMANUEL EIMIOMODEBHEKI ODION ${ }^{1}$, NADJA ENGEL- LUTZ ${ }^{2}$,}

